\title{
Urban Expansion and Loss of Agricultural Land in Osogbo, Osun State Nigeria, using Multi-Temporal Imageries
}

\author{
Afolabi Francis Fatusin ${ }^{1}$, Gbenga John Oladehinde ${ }^{2}$, and Victor Ojo ${ }^{3}$ \\ ${ }^{1}$ Department of Geography and Planning Sciences, Adekunle Ajasin University, Nigeria. \\ 2 Department of Urban and Regional Planning, Obafemi Awolowo University, Nigeria. \\ ${ }^{3}$ Department of Urban and Regional Planning, Osun State University, Nigeria.
}

To cite this article: Fatusin, A.F., Oladehinde, G.J. \& Ojo, V. (2019). Urban Expansion and Loss of Agricultural Land in Osogbo, Osun State Nigeria, using Multi-Temporal Imageries. Journal of African Real Estate Research, 4(1), pp.139-156. DOI: 10.15641/jarer.v4i1.735.

\begin{abstract}
Osogbo, the state capital of Osun State is one of the rapidly urbanizing cities in Nigeria. This article examined urban expansion and the transition of agricultural land in Osogbo with the use of multi-temporal imageries between 1986 and 2018. Large amounts of cultivated land has been transformed into other land uses in the past 31 years. This paper presents the process of the loss of agricultural land and urban growth in Osogbo with the use of remote sensing and GIS. Landsat imageries for 1986, 2002 and 2018 were used to analyse land use and land cover change. Supervised image classification was applied to classify the images into different land use categories. Six land use classes were identified: built-up area, water body, cultivated area, gallery zone, dense vegetation and rocky outcrops. Built-up areas (residential, educational and industrial areas) have greatly increased while agricultural lands (i.e. farmland and wetland) have considerably decreased during the study period. Built-up area covered $7.06 \%$ in 1986 but increased to $53.61 \%$ in 2018 while agricultural land decreased from $86.28 \%$ to $41.53 \%$ in the same period. The study therefore recommends that government should integrate agricultural lands into urban land use, planning for efficient management and protection of the dwindling agricultural space.
\end{abstract}

Keywords: Urban expansion; Geographical Information Systems; Loss of Agricultural Land; Land-use; Land Cover 


\section{Introduction}

Agriculture is an important economic activity in many parts of the world, especially developing countries in Asia and Sub-Saharan Africa (Naab et al., 2013; Enaruvbe \& Atedhor, 2015). Not only does it serve as the provider of employment opportunity, but also as a means of supplying fresh food for both urban and rural dwellers. This is particularly the case in developing countries. Agriculture involves growing, processing and distributing food and other products through plant cultivation and raising livestock in rural areas and cities (Kulak et al., 2013). Cultivation of crops, especially in and around cities, is refered to as urban agriculture. According to Mougeot (2005), urban agriculture is an industry located within (intra-urban), or on the fringes (periurban) of a town, city or metropolis. Further, urban agriculture is responsible for growing, processing and distributing a diversity of food and non-food products, using largely human and material resources, products and services found in and around an urban area. Then, in turn, supplying human and material resources, products and services largely to that same urban area. Urban agriculture is a common phenomenon which has existed for a long time. Urban agriculture has assumed global concern and become a topic of scientific research in recent times. This is as a result of the increasing growth of hunger in most parts of the world and has presently become a huge challenge for government in most developing nations.

Studies have shown that the importance of urban agriculture cannot be underestimated. This is as a result of its contribution to global food stocks. For instance, UN-Habitat (2008) reported that urban agriculture has produced between $15 \%$ and $20 \%$ of the world's food and involved over 800 million urban and peri-urban dwellers. Out of this estimated figure, about 200 million are considered to be market producers, employing approximately 150 million people on a full-time basis. In support of this assertion, Fournier (1996) noted that urban agriculture has contributed significantly to food security and safety for approximately $50 \%$ of the world's population that are city dwellers. Similar studies in Sub-saharan Africa (Nugent, 2000; Cofie et al., 2003) have also shown that the contribution of urban agriculture is on the increase. In another dimension, urban agriculture has become a significant source of job creation for the urban unemployed, improved livelihood and sustained urban ecology. Rees (1997) observed that about a fifth to a third of families in some cities are engaged in urban agriculture with some not having alternative sources of sustenance or income. Urban agriculture has sustained the livelihood of low income dwellers in developing countries for many years (Addo, 2010).

However, despite the contribution of urban agriculture to the world's food and employment, its practice in recent years has decreased, especially in most cities in Sub Saharan Africa, including Nigeria. This is as a result of rapid environmental change, occasioned by a rapid population growth and ruralurban infrastructure inequality (Enaruvbe \& Atedhor, 2015). Rapid population growth has also resulted in increased physical development on urban edible spaces such as farmland, wetland and open space along arterial roads (Ajibola, Adewale \& Ijasan, 2012). This development threatens the 
sustainability of urban agriculture since the practice is influenced considerably by changing land use and land cover patterns (Addo, 2010).

The integration of Geographical Information Systems (GIS) and remote sensing has been widely applied and recognised as a powerful and efficient tool in detecting agricultural change, urban land use and land cover change (Ashbindu et al., 2001). GIS is a technology which provides a flexible environment for entering, analysing and displaying digital data from various sources necessary for urban feature identification, change detection and database development (Mir et al., 2016). Satellite remote sensing collects multi-resolution, multi-spectral and multi-temporal data and turns them into information valuable for understanding and monitoring urban land process, and for building urban land cover datasets (Yuan et al., 2005). To this end, it is very important that remote sensing and GIS are used in analysing urban expansion and loss of agricultural land.

The creation of Osun State and the subsequent sitting of the capital in Osogbo have brought about an increase in population and human activities, land use dynamics, and by extension, urban expansion. The expansion and growth of Osogbo has not only impacted the socio-economic dynamics of the area, but it has also affected various land uses in the city, most especially agricultural land (i.e. conversion of wetland, farmland and other environmental resources for urban use). Significant studies have been made in different parts of the world to address land use changes using GIS (Schmidt \& Kedir, 2009; Kharel, 2010; Kumar \& Kumar, 2016). Nevertheless, none of these studies have combined different resolution data such as Landsat Thematic Mapper (TM); Enhanced Thematic Mapper Plus (ETM+); and Operational Land Imager and Thermal Infrared Sensor (OLI-TIRS) in measuring land use change or loss estimation in developing countries. Also, several studies in Nigeria have examined various aspects of environmental change, particularly land cover dynamics (Adeniyi \& Omojola, 1999; Fabiyi, 2006; Braimoh \& Onishi, 2008; Tokula \& Ejaro, 2013; Oloukoi, Oyinloye \& Yadjemi, 2014; Dekolo, Oduwaye \& Nwokoro, 2016). However, recent and up-to-date studies on the effects of urban growth on agricultural land are scanty in the literature. There is therefore a need to examine urban expansion and loss of agricultureal land in Osogbo, Osun State Nigeria, using multi-temporal imageries.

Based on the foregoing, this study aims at analysing agricultural land use change in Osogbo over the last three decades using geo-information technologies. The specific objectives of the study is to analyse the pattern and rate of land use change in and around Osogbo using multi-temporal imageries, and determine the impact of the observed changes on agricultural land use in the study area.

\section{Study Area}

The study area covered Osogbo, the capital city of Osun state and its environment. Osogbo has two Local Government Areas (LGAs). These include Osogbo and Olorunda LGAs. The study area is located between latitude $7^{\circ} 46^{\prime} \mathrm{N}$ and $7.767^{\circ} \mathrm{N}$ and longitude $4^{\circ} 34^{\prime} \mathrm{E}$ and $4.567^{\circ} \mathrm{E}$ (see Figure 1, 
2 and 3). Osogbo, which contain a population of 715306 , has become a major urban centre of since the colonial period. Osogbo is a commercial and industrial centre. This started in 1907 when the British Cotton Growing Association sited an industry for growing and ginning of cotton. In this same year the Nigerian Tobacco Company (NTC) built its first factory in Osogbo. The above was a major turning point for the city which helped trigger its industrial and commercial development. Later, railway tracks were constructed linking it to other parts of Northern Nigeria. This attracted people from far and near. Osogbo shares boundaries with Ikirun, Ilesha, Ede, Egbedore and Iragbiji and is easily accessible from any part of the state because of its central location. It is about $48 \mathrm{~km}$ from Ife, $32 \mathrm{~km}$ from Ilesa, $46 \mathrm{~km}$ from Iwo, $48 \mathrm{~km}$ from Ikire and 46km from Ila-Orangun (osun.gov.ng).

The arrival of the railway in 1970 transformed Osogbo into a commercial town which brought about the colonial government to the threshold of the town. Settlers and immigrants were attracted to Osogbo as a result of industrial and commercial development. Some of the commercial and industrial establishments which are widely spread across the study area include: a lead pencil manufacturing factory, sawmills, motor vehicle garages, Osogbo steel rolling company, wire and nails industry, plastic pipe factory, agro allied industry, and hotels and garment industries, among others.

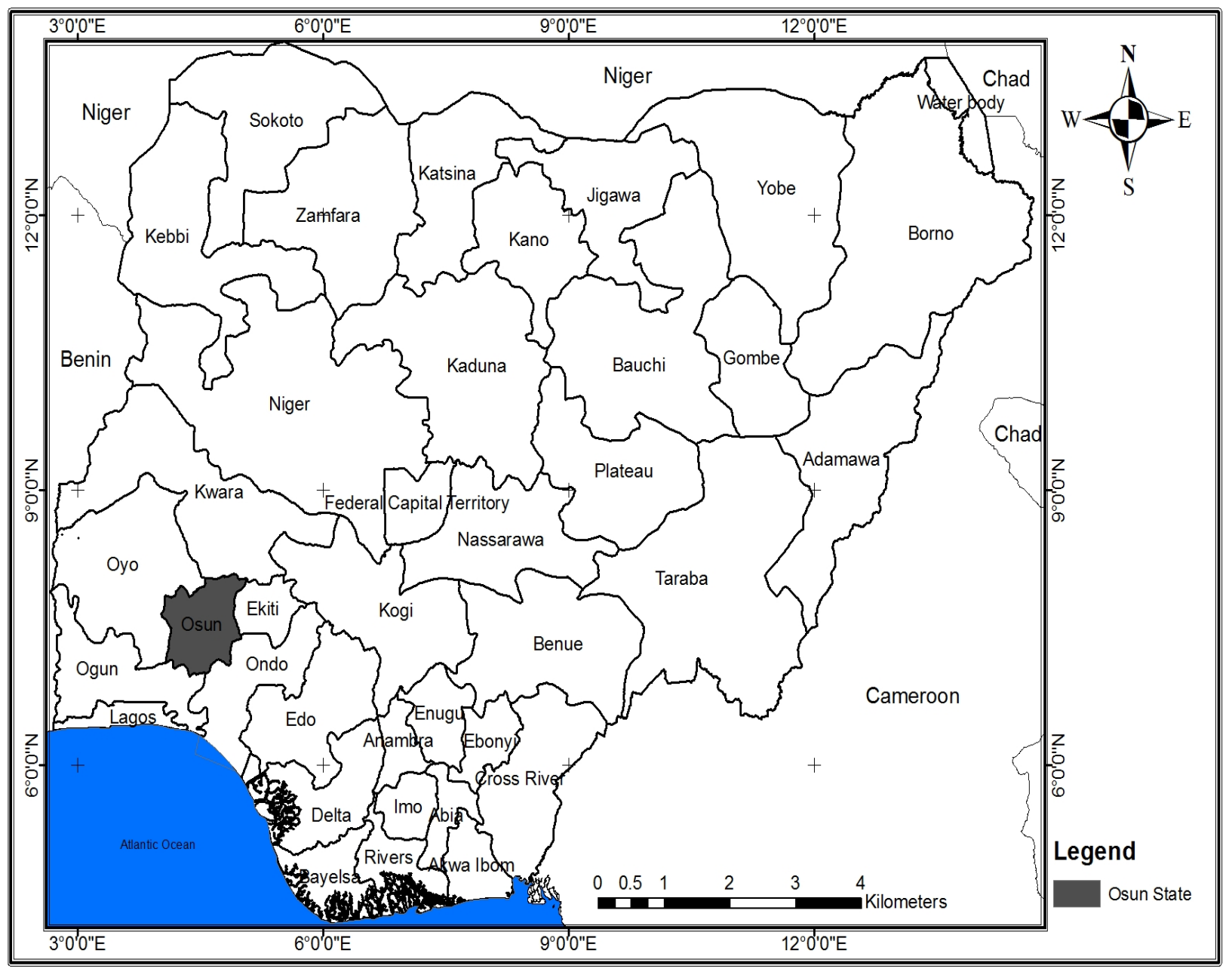

Figure 1: Osun State in the Context of Nigeria. 
Source: Cooperative Information Network (COPINE) (2018)

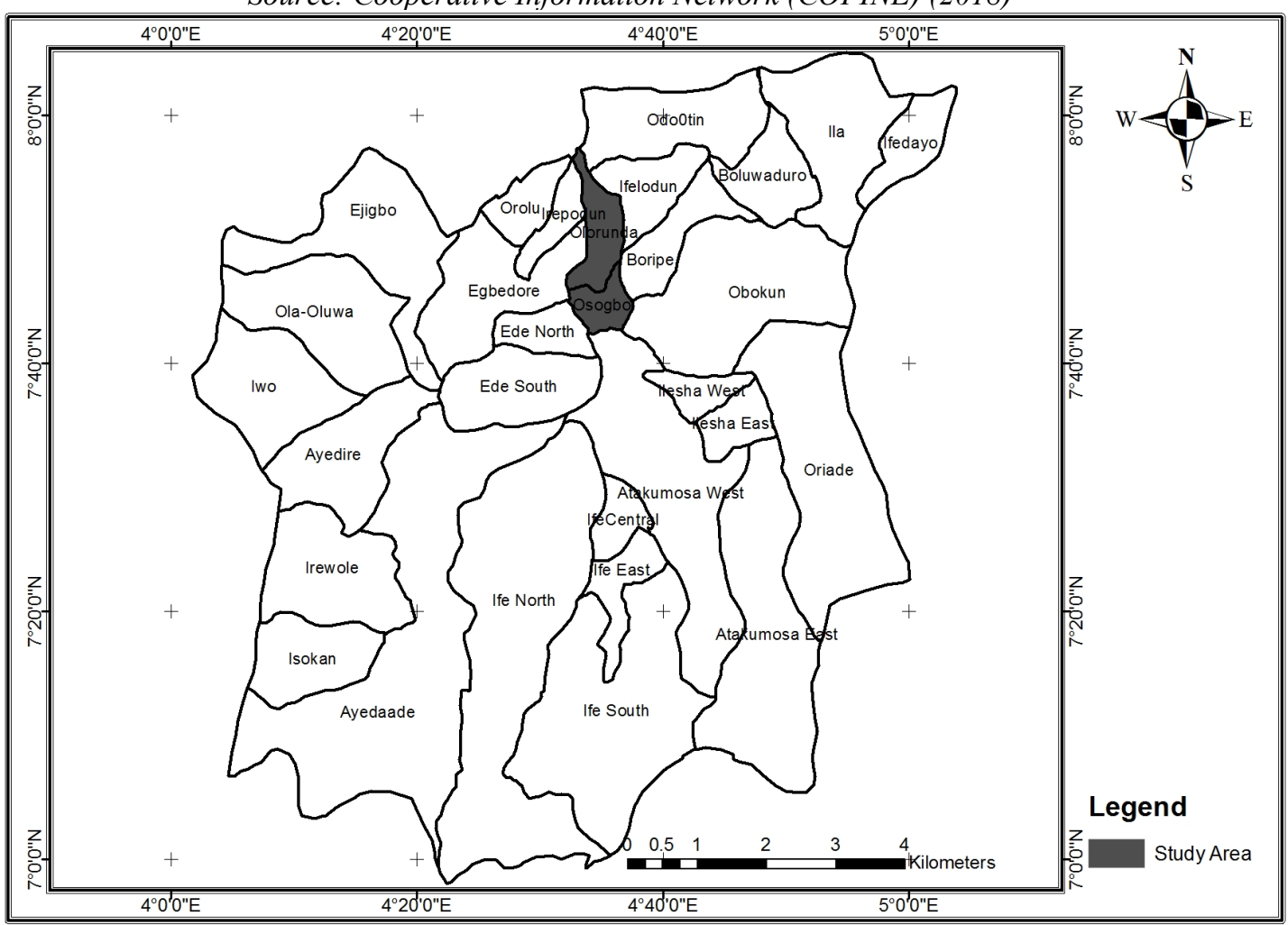

Figure 2: Olorunda and Osogbo Local Government Area in the Context of Osun State.

Source: Cooperative Information Network (COPINE) (2018)

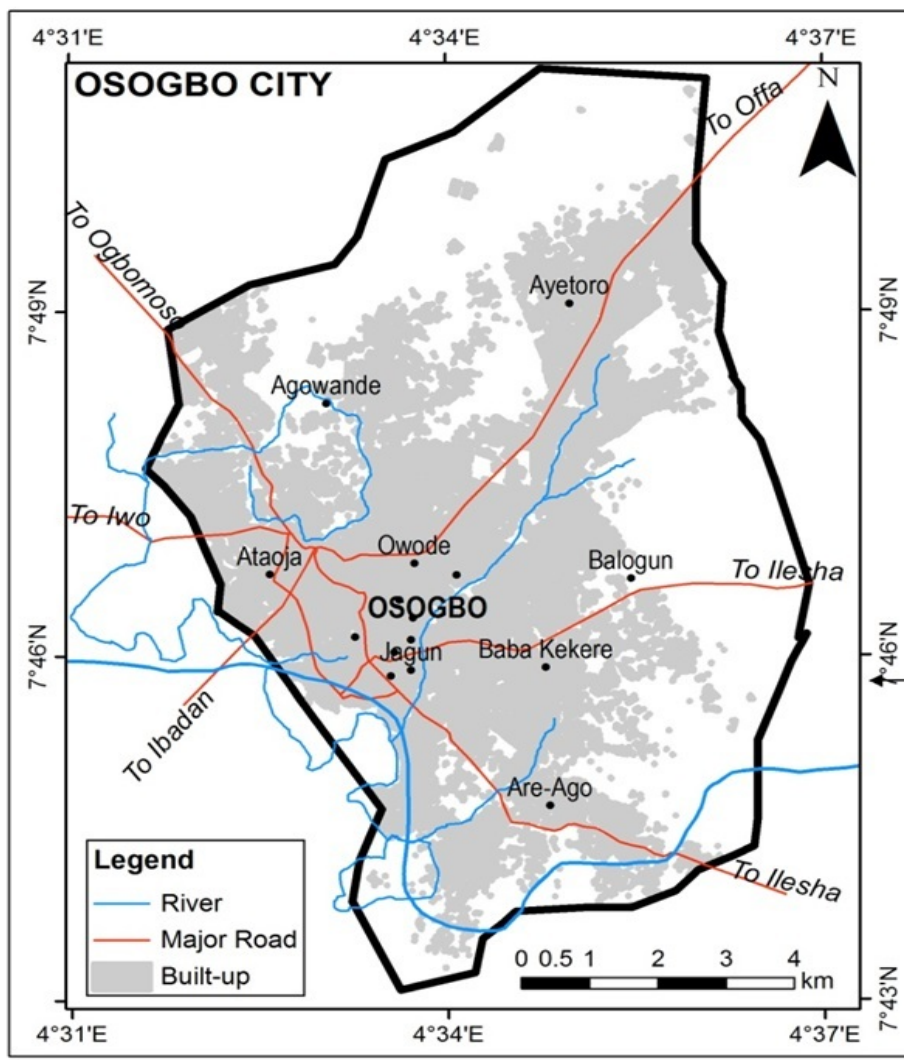

Figure 3: Map of the Study Area

Source: Cooperative Information Network (COPINE) (2018) 


\section{Materials and Methods}

Both primary and secondary data were employed for this study. The primary data was collected on the physical attributes of six key land use types for this study. The sample sites were determined from the remotely sensed imageries that were used for the study. The secondary data sources were Landsat ${ }^{1} 5 \mathrm{TM}$, Landsat 7 ETM+ and Landsat 8 OLI covering the area, and Aster Data from the United States Geographical Survey. The primary dataset was summarized for eventual integration with the spatial datasets. The processing and analysis of secondary data included: image enhancement, geometric correction, variable combination of spectral bands for land use mapping, and a creation of a database for handling the various data types. These operations were performed using ILWIS software version 3.4, Arc View 3.2 and AutoCAD Map R2 to bring out the classes of land use types currently dominant in the area. The resulting land use characteristics are compared to assess the changes that have taken place on agricultural land (wetland and farmland) in quantitative and qualitative terms.

The following land use and land cover types were identified after satisfactory visual interpretation of the images: water bodies, riparian zones/gallery forest, dense vegetation, cultivated land, rocky outcrop, built-up area. The built-up area comprises buildings and other artificial structures. Water bodies include the areas covered mainly with surface water: rivers, creeks, reservoirs and ponds. Riparian zones/gallery forests are regions covered with trees of different species with little or no human activities. Dense vegetation represents area consisting of trees of different species and sizes, shrubs and woody plants. Cultivated land includes area used for growing agricultural crops during the wet and dry season (i.e. farmland and wetlands). Rocky outcrops are exposed land, such as mountain, hill and highland. The visual interpretation was done by means of the interpretation keys such as: size, shape, pattern, texture, tone, colour and association of the features. After this, the images were classified using the supervised classification techniques. The maximum likelihood algorithm was used in order to compare the various land use features and assess them before drawing meaningful inferences (Yuan et al., 2005; Wu et al., 2006).

The data used for the extraction of the land cover information in the study area include; landsat: 1986, 2002 and 2018 and GPS observations of points of interest such as new built-up areas, farmlands, water bodies, and bare lands in the study. All these images were acquired from Global Earth Geo-systems (see Table 1).

\footnotetext{
${ }^{1}$ Landsat refers to a programme which consists of a series of optical/infrared remote sensing satellites for creating accurate and quality imagery to enable observation of the changing landscape of Earth.
} 
Table 1: Summary of Landsat Images Acquired for the Research

\begin{tabular}{|c|c|c|c|c|c|c|c|}
\hline Date & $\begin{array}{c}\text { Satellite } \\
\text { Number }\end{array}$ & Band & $\begin{array}{c}\text { Sensor } \\
\text { type }\end{array}$ & $\begin{array}{c}\text { UTM } \\
\text { Zone }\end{array}$ & Datum & $\begin{array}{c}\text { Scale/ } \\
\text { Resolution }\end{array}$ & $\begin{array}{c}\text { Sources } \\
\text { and Year }\end{array}$ \\
\hline 1986 & Landsat 5 & $4,3,2$ & TM & $31 \mathrm{~N}$ & WGS84 & $28.5 \mathrm{~m}$ & USGS, 1986 \\
\hline 2002 & Landsat 7 & $4,3,2$ & ETM+ & $31 \mathrm{~N}$ & WGS84 & $28.5 \mathrm{~m}$ & USGS, 2002 \\
\hline 2018 & Landsat 8 & $4,3,2$ & OLI_TIRS & $31 \mathrm{~N}$ & WGS84 & $28.5 \mathrm{~m}$ & USGS, 2018 \\
\hline & $\begin{array}{c}\text { GPS } \\
\text { observation }\end{array}$ & & & & & & \\
\hline
\end{tabular}

\section{Population Growth}

Population figure of 1986, 2002 and 2018 were estimated from the provisional result of 1991 and 2006 population census of about 189733 and 287156 respectively. The result of the estimated figure was projected with the formula below:

$$
\operatorname{Pr}=\mathrm{P} 0(1+\mathrm{r} / 100)^{\wedge} \mathrm{n}
$$

Where: $\quad \operatorname{Pr}=$ the projected population

$\mathrm{P} 0=$ the existing population

$\mathrm{r}=$ the growth rate $(3.2 \%)$

$\mathrm{n}=$ the number of years

$\mathrm{r}(3.2 \%)$ is constant for all the years, $\mathrm{n}$ is -5 in $1986,-4$ in 2002 and 12 in 2018.

Therefore population in $1986=189733(1+3.2 / 100)^{\wedge}-5=\mathbf{1 6 2} \mathbf{0 8 5 . 6}$

Population in $2002=287156(1+3.2 / 100)^{\wedge}-4=\mathbf{2 5 3} \mathbf{1 6 2 . 3}$

Population in $2018=287156(1+3.2 / 100)^{\wedge} 12=\mathbf{4 1 9} \mathbf{0 5 8 . 1}$

Note: The population figures were obtained by interpolation using the annual growth rate of $3.2 \%$ of Osogbo and Olorunda Local government areas (Gasu et al., 2016).

\section{Statistical Methods}

The comparative study of land use/land cover was adopted by identifying the trend and percentage of changes between 1988 to 2002 and 2002 to 2018 . In achieving this, the first task was to develop the tables showing the area in hectare (ha) and percentage of change between 1988 to 2002 and 2002 to 2018. This was measured in each and every land use/land cover category. The change of percentage is used to determine the trend of change and was calculated by dividing observed changes by the sum of the changes. The second task was the use of compound growth rate $(\mathrm{R})$ in the measurement of the rate of change in land use types. The compound growth rate $(\mathrm{R})$ of each land use between 1988 to 2002 and 2002 to 2018 was determined using the formula below:

$$
\mathrm{R}=\left(\mathrm{U}_{\mathrm{T}} / \mathrm{U}_{0}\right)^{1 / \mathrm{T}}-1
$$

Where: $\quad \mathrm{U}_{\mathrm{T}}=$ size of the land use at the end of the period

$\mathrm{U}_{0}=$ size of the land use at the beginning of the period

$\left(\mathrm{U}_{\mathrm{T}} / \mathrm{U}_{0}\right)^{1 / \mathrm{T}}=$ Tth root of the quotient

$\mathrm{T}=$ length of time 


\section{Results and Discussion}

Results in Table 2 show the analysis of land use in hectares per year and percentage per year between 1986 and 2018 (illustrated on the grah in Figure 4 ). This was derived from land use and land cover comparison analysis in the study area. The main categories of land uses identified in the study area include: water body, riparian zones/gallery forest, dense vegetation, bare land/cultivated area, rocky outcrops and built-up area (Table 2). The pixel statistics of land use in Landsat TM 1986 presented in Table 2 (see Figure 5) shows that the area covered by water body and rocky outcrops were $623.56 \mathrm{ha}$ and 361.53 ha representing $4.21 \%$ and $2.44 \%$ respectively of the study area. Riparian zones and dense vegetation accounted for $8782.36 \mathrm{ha}(59.34 \%)$ of the entire area. Built-up areas accounted for $4.21 \%$ (1044.71 ha) of the study area. The land use and land cover classes in 1986 shows that much development had not taken place in the study area. The proportion of cultivated area in 1986 shows that the majority of the residents in the study area are farmers.

In 2002, natural vegetation (gallery forest and dense vegetation) was still the dominant land cover class with 8127.93 ha covering approximately $55.09 \%$ of the study area. The pixel covering cultivated area (3 834.92ha) accounted for $25.98 \%$ of the entire area in 2002 . This shows that the majority of the populace were still actively involved in farming between 1986 and 2002 (see Figure 6). The pixel representing rocky outcrops was $439.02 \mathrm{ha}(2.97 \%)$. Water bodies had reduced to $2.16 \%$ (329.864ha) while built-up area increased to $13.78 \%$ (2 $033.06 \mathrm{ha})$.

The 2018 imagery (see Figure 7) showed that built-up areas have increased to $53.61 \%$ (7 934.06ha) of the study area. The proportion of gallery forest and dense vegetation has reduced to 1000.53 ha and 3110.02 ha representing $6.76 \%$ and $21.01 \%$ coverage of the entire study area respectively. Water bodies, rocky outcrops and cultivated areas account for 358.83ha $(2.42 \%)$, 359.64 ha $(2.43 \%)$ and 2036.07 ha $(13.76 \%)$ respectively. This shows that between 1986 and 2002, there was not much development, as considerable numbers of the residents were involved in farming. However, between 2002 and 2018, there was a massive inflow of migrants. This contributed to urban expansion (increase in the number of the built-up areas). The consequence of this massive inflow of migrants to the study area is the declination of agricultural land. The rapid increase in urbanisation coupled with an increasing population led to the conversion of vegetation, wetland and farmland to other uses such as residential, educational, commercial and industrial development. 
Table 2: LULC Distribution between 1986 and 2018

\begin{tabular}{|l|c|c|c|c|c|c|}
\hline \multirow{2}{*}{ Land Use Type } & \multicolumn{2}{|c|}{$\mathbf{1 9 8 6}$} & \multicolumn{2}{c|}{$\mathbf{2 0 0 2}$} & \multicolumn{2}{c|}{$\mathbf{2 0 1 8}$} \\
\cline { 2 - 7 } & $\begin{array}{c}\text { Areal Extent } \\
\text { (ha) }\end{array}$ & $\mathbf{\%}$ & $\begin{array}{c}\text { Areal } \\
\text { Extent (ha) }\end{array}$ & $\mathbf{\%}$ & $\begin{array}{c}\text { Areal } \\
\text { Extent (ha) }\end{array}$ & $\%$ \\
\hline Water Body & 623.56 & 4.21 & 319.864 & 2.16 & 358.83 & 2.42 \\
\hline $\begin{array}{l}\text { Riparian Zones/gallery } \\
\text { Forest }\end{array}$ & 2815.82 & 19.03 & 3217.48 & 21.81 & 1000.53 & 6.76 \\
\hline Dense Vegetation & 5966.54 & 40.31 & 4910.45 & 33.28 & 3110.02 & 21.01 \\
\hline Cultivated land & 3987.65 & 26.94 & 3832.92 & 25.98 & 2036.07 & 13.76 \\
\hline Rock Outcrop & 361.53 & 2.44 & 439.021 & 2.97 & 359.64 & 2.43 \\
\hline Built-Up Areas & 1044.71 & 7.06 & 2033.061 & 13.78 & 7934.06 & 53.61 \\
\hline Total & $\mathbf{1 4 7 9 9 . 8 1}$ & $\mathbf{1 0 0}$ & $\mathbf{1 4 7 5 2 . 7 9 6}$ & $\mathbf{1 0 0}$ & $\mathbf{1 4 7 9 9 . 1 5}$ & $\mathbf{1 0 0}$ \\
\hline
\end{tabular}

Source: Authors' survey, 2018

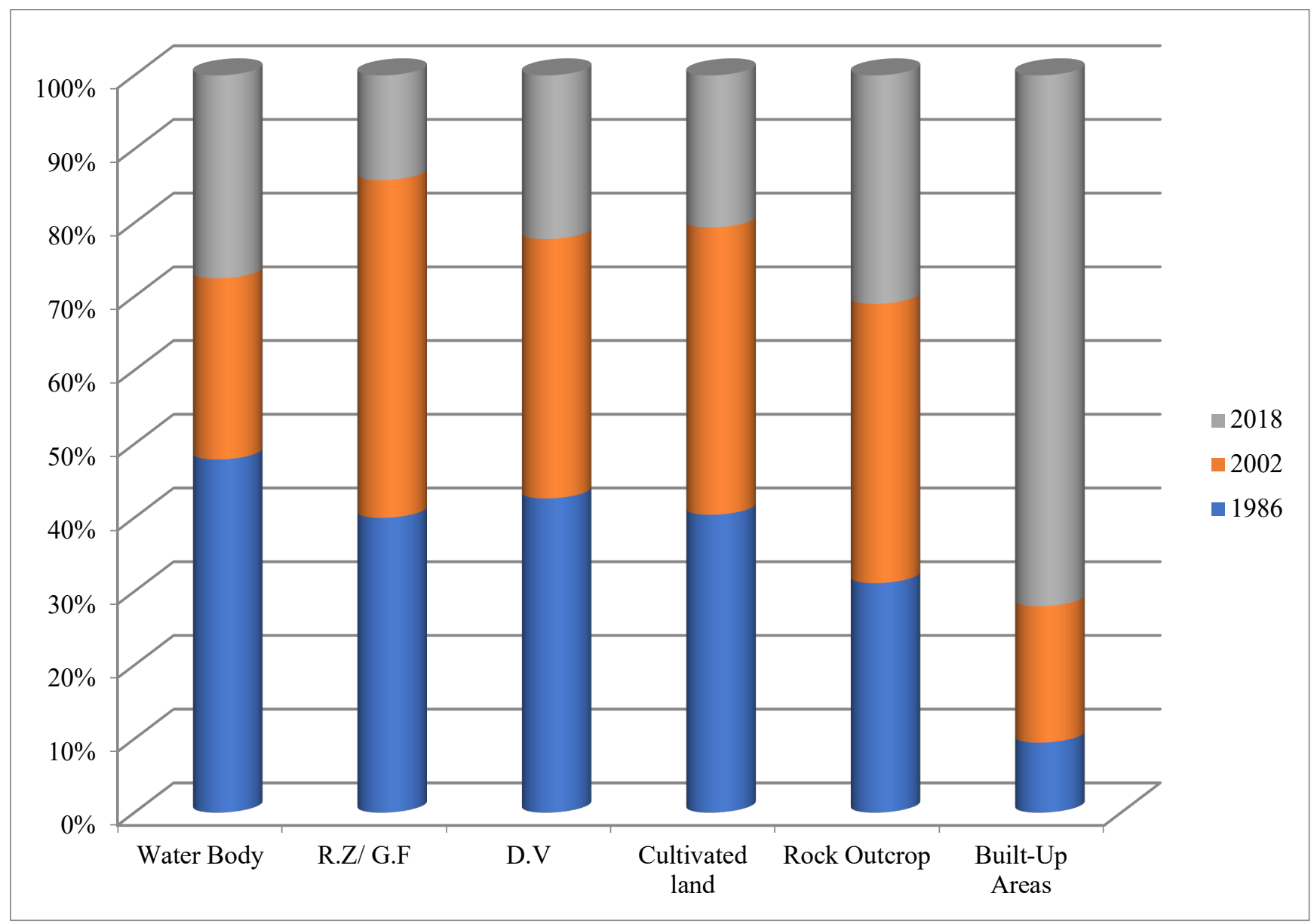

Figure 4: Comparative Gain and Loss of Land use/changes between 1986 and 2018

Source: Authors' survey, 2018 
Journal of African Real Estate Research Volume 4(1) 2019

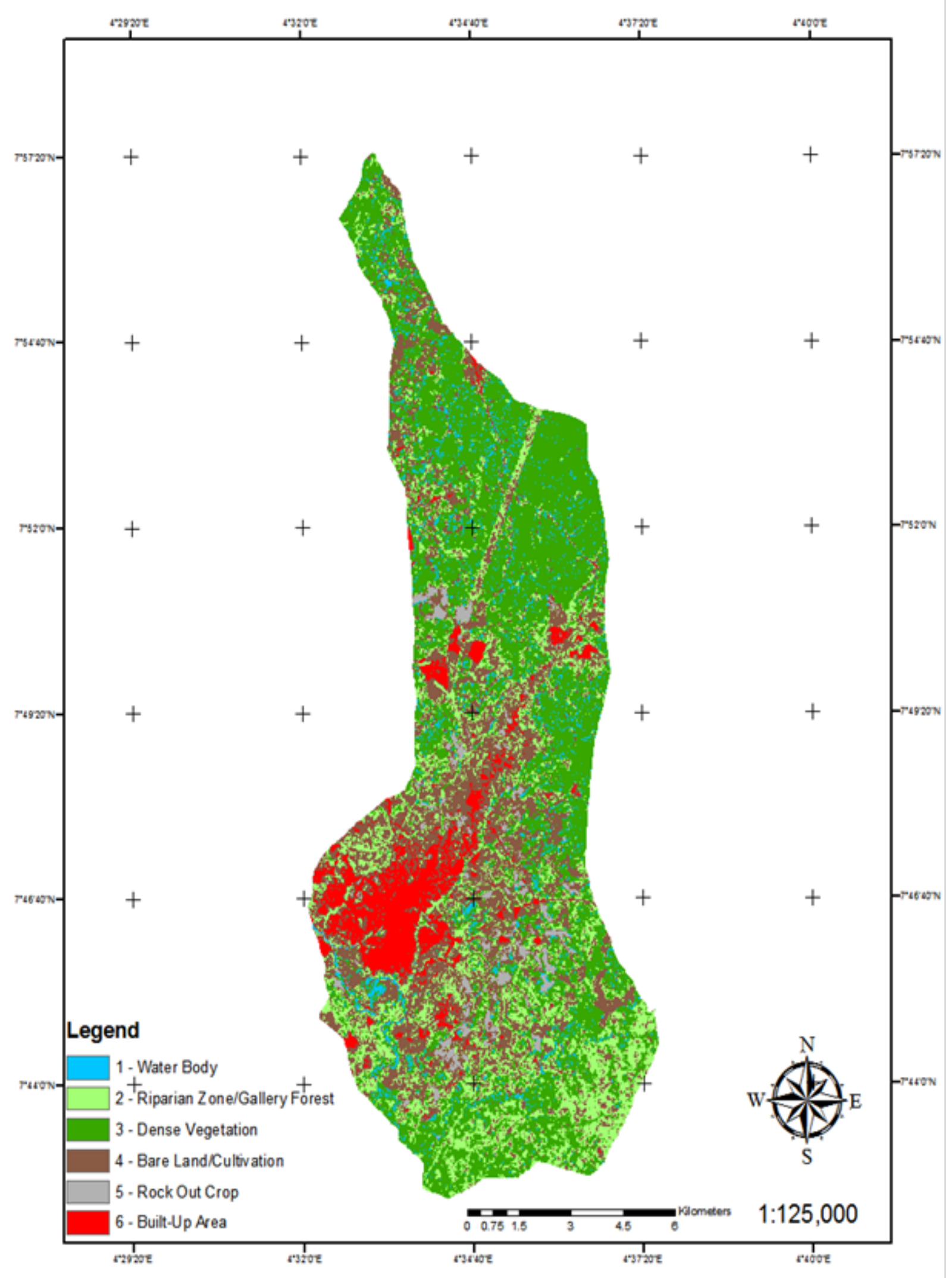

Figure 5: Land use and land cover Map of Osogbo, 1986

Source: Authors Lab Work, 2018. 


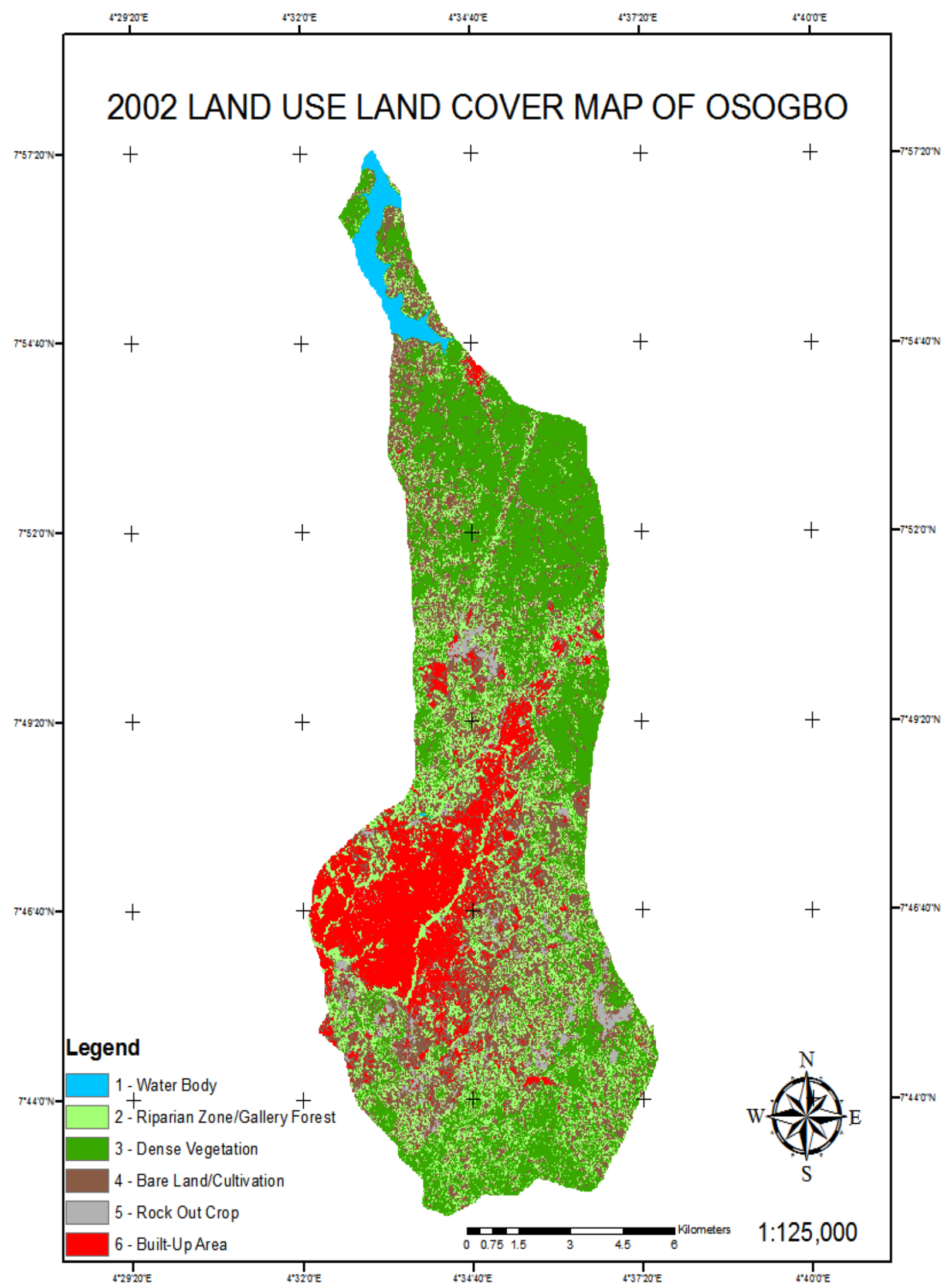

Figure 6: Land use and land cover Map of Osogbo, 2002

Source: Authors Lab Work, 2018 
Journal of African Real Estate Research Volume 4(1) 2019

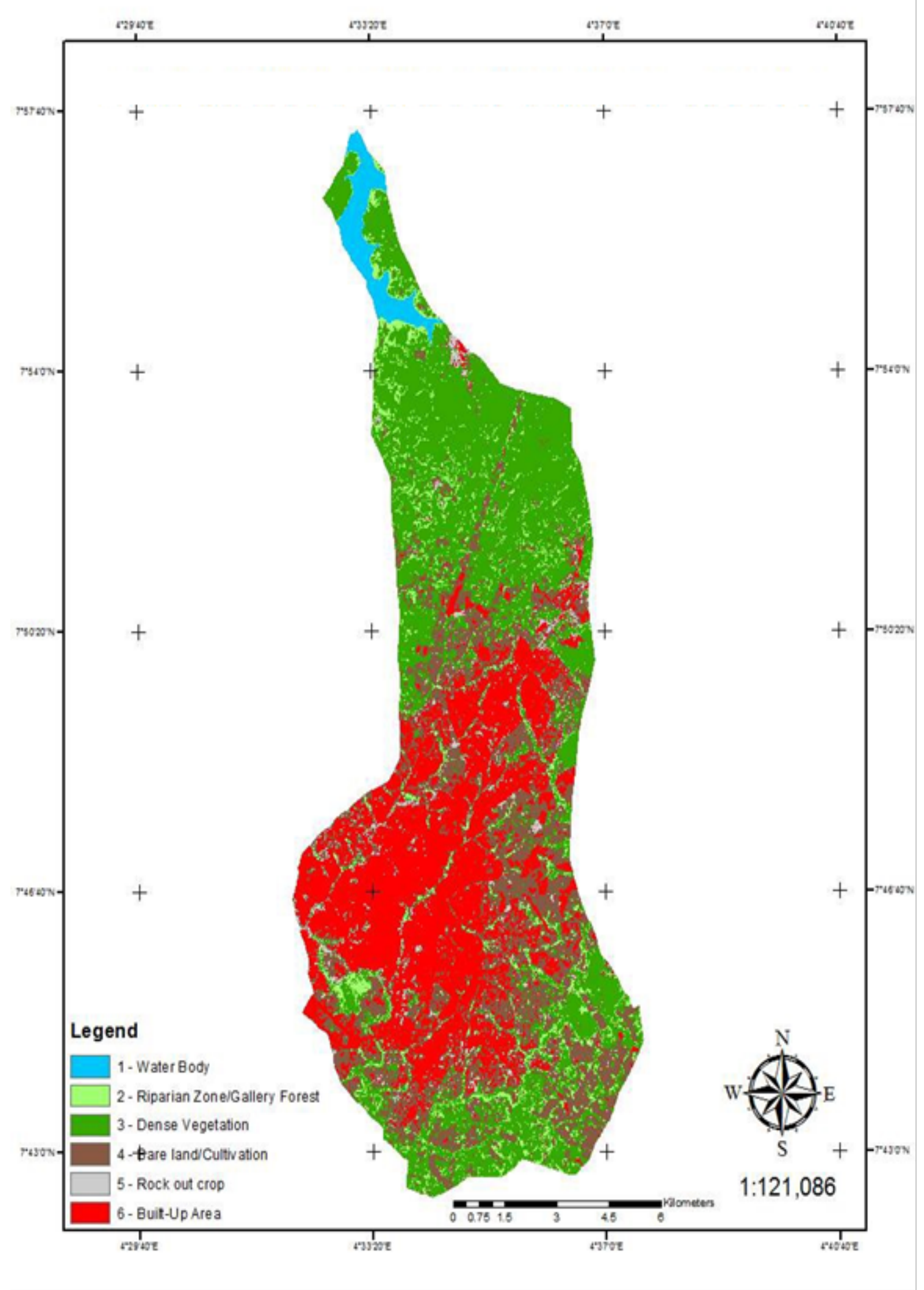

Figure 7. Land Use/Land Cover of Osogbo, 2018

Source: Authors' Lab work, 2018 
Table 3 shows the changes (in hectares and percentage) in land cover that have occurred between 1986 and 2002 (within 16 years). The result shows that the compound rate of land cover changes in hectare per year between 1986 and 2002. The compound rate of change of cultivated area between 1986 and 2002 was $-9.67 \mathrm{ha} / \mathrm{yr}$ at $-0.25 \%$ per year. This implies that for every year, cultivated area reduced at an compound rate of $-0.25 \%$.

Table 3: LULC Change and Rates of Change between 1986 and 2002

\begin{tabular}{|c|c|c|c|c|c|c|c|c|}
\hline \multirow[t]{2}{*}{ Land Use Type } & \multicolumn{2}{|c|}{1986} & \multicolumn{2}{|c|}{2002} & \multicolumn{2}{|c|}{$\begin{array}{c}\text { Changes between } \\
1986 \text { and } 2002\end{array}$} & \multicolumn{2}{|c|}{$\begin{array}{l}\text { Compound Rate of } \\
\text { change between } 1986 \\
\text { and } 2002\end{array}$} \\
\hline & ha & $\%$ & ha & $\%$ & ha & $\%$ & (ha/yr) & $\mathbf{R}(\%)$ \\
\hline Water Body & 623.56 & 4.21 & 319.864 & 2.16 & -303.696 & -48.7 & -18.98 & -4.09 \\
\hline $\begin{array}{l}\text { Riparian } \\
\text { Zones/gallery Forest }\end{array}$ & 2815.82 & 19.03 & 3217.48 & 21.81 & +401.66 & 14.26 & 25.1 & 0.84 \\
\hline Dense Vegetation & 5966.54 & 40.31 & 4910.45 & 33.28 & -1056.09 & -17.7 & -66.01 & -1.21 \\
\hline Cultivated land & 3987.65 & 26.94 & 3832.92 & 25.98 & -154.73 & -3.88 & -9.67 & -0.25 \\
\hline Rock Outcrop & 361.53 & 2.44 & 439.021 & 2.97 & +77.491 & 21.43 & 4.84 & 1.22 \\
\hline Built-Up Areas & 1044.71 & $\frac{2.75}{7.06}$ & 2033.061 & 13.78 & +988.35 & 94.6 & 61.77 & 4.25 \\
\hline Total & 14799.81 & 100 & 14752.80 & 100 & & & & \\
\hline
\end{tabular}

Source: Authors'survey, 2018

Table 4 shows the changes (in hectares and percentage) in land cover that have occurred between 2002 and 2018 (within 16 years). The result shows the compound rate of land cover change in hectare per year between 2002 and 2018. The compound rate of change of built-up area was $393.4 \mathrm{ha} / \mathrm{yr}$. This implies that the rate of change in built-up areas for every year between 2002 and 2018 has increased significantly at a compound rate of $393.4 \mathrm{ha} / \mathrm{yr}$ amounting to $9.5 \%$ every year. This shows that there was rapid rate of urbanization in the study area between 2002 and 2018. The table also shows an increase in water bodies $+2.6 \mathrm{ha} / \mathrm{yr}(-0.77 \%)$. This is due to the establishment of dam at the northern part of the study area. Furthermore, the result shows a decrease in cultivated land at a compound rate of $-119.79 \mathrm{ha} / \mathrm{yr}$. It can be inferred that most of the farmland and wetland within the urban centre have been converted to other land uses which are non-agricultural in nature. The result shows a decrease in the riparian zones/gallery forest (-147.8 $\mathrm{ha} / \mathrm{yr})$ and dense vegetation (-120.03 ha/yr) in the study area.

Table 4. LULC Change and Rates of Change between 2002 and 2018

\begin{tabular}{|c|c|c|c|c|c|c|c|c|}
\hline \multirow[t]{2}{*}{ Land Use Type } & \multicolumn{2}{|c|}{2002} & \multicolumn{2}{|c|}{2018} & \multicolumn{2}{|c|}{$\begin{array}{c}\text { Changes between } \\
2002 \text { and } 2018\end{array}$} & \multicolumn{2}{|c|}{$\begin{array}{l}\text { Compound Rate of } \\
\text { change between } 2002 \\
\text { and } 2018\end{array}$} \\
\hline & ha & $\%$ & ha & $\%$ & ha & $\%$ & (ha/yr) & $\mathbf{R}(\%)$ \\
\hline Water Body & 319.864 & 2.16 & 358.83 & 2.42 & +38.97 & +12.2 & +2.6 & -0.77 \\
\hline $\begin{array}{l}\text { Riparian } \\
\text { Zones/gallery Forest }\end{array}$ & 3217.48 & 21.81 & 1000.53 & 6.76 & -2216.95 & -68.9 & -147.8 & -7.49 \\
\hline Dense Vegetation & 4910.45 & 33.28 & 3110.02 & 21.01 & -1800.43 & -36.67 & -120.03 & -3.0 \\
\hline Cultivated land & 3832.92 & 25.98 & 2036.07 & 13.75 & -1796.85 & -46.88 & -119.79 & -4.13 \\
\hline
\end{tabular}




\begin{tabular}{|l|c|c|c|c|c|c|c|c|}
\hline Rock Outcrop & 439.021 & 2.97 & 359.64 & 2.43 & -79.38 & -18.1 & -5.29 & -1.32 \\
\hline Built-Up Areas & 2033.061 & 13.78 & 7934.06 & 53.61 & +5900.9 & +290.25 & +393.4 & 9.5 \\
\hline Total & $\mathbf{1 4 7 5 2 . 8 0}$ & $\mathbf{1 0 0}$ & $\mathbf{1 4 7 9 9 . 1 5}$ & $\mathbf{1 0 0}$ & & & & \\
\hline
\end{tabular}

Source: Authors' survey, 2018

Table 5 shows the changes in land use that have occurred between 1986 and 2018 in hectares and percentage. It was observed that between 1986 and 2002, built-up area increased by 988.35 (94.6\%) and rapidly increased by 5900.9 (290.25\%) between 2002 and 2018. It can be inferred that the amount of builtup areas is on the increase. This could be attributed to population growth, urban expansion, industrialization, housing expansion, among others (see Table 7). Conversely, the riparian zones/gallery forest, dense vegetation and cultivated areas were on the decrease between 1986 and 2002; 2002 and 2018.

Table 5. Change in Land Use between 1986 and 2018

\begin{tabular}{|l|c|c|c|c|}
\hline \multirow{2}{*}{ Land Use Type } & \multicolumn{2}{c|}{$\begin{array}{c}\text { Changes between 1986 } \\
\text { and 2002 }\end{array}$} & \multicolumn{2}{c|}{$\begin{array}{c}\text { Changes between 2002 } \\
\text { and 2018 }\end{array}$} \\
\cline { 2 - 5 } & (ha) & $\mathbf{\%}$ & (ha) & \% \\
\hline Water Body & -303.696 & -48.7 & +38.97 & +12.2 \\
\hline $\begin{array}{l}\text { Riparian Zones/gallery } \\
\text { Forest }\end{array}$ & +401.66 & 14.26 & -2216.95 & -68.9 \\
\hline Dense Vegetation & -1056.09 & -17.7 & -1800.43 & -36.67 \\
\hline Cultivated land & -154.73 & -3.88 & -1796.85 & -46.88 \\
\hline Rock Outcrop & +77.491 & +21.43 & -79.38 & -18.1 \\
\hline Built-Up Areas & +988.35 & +94.6 & +5900.9 & +290.25 \\
\hline
\end{tabular}

Source: Authors' survey, 2018

Table 6. Analysis of Urban expansion in ha/year and \% per year

\begin{tabular}{|c|c|c|c|c|c|c|c|}
\hline \multirow[t]{2}{*}{ Year } & \multirow{2}{*}{$\begin{array}{c}\text { Urban } \\
\text { (Built-up Area) }\end{array}$} & \multicolumn{2}{|c|}{ Change } & \multirow{2}{*}{$\begin{array}{c}\text { Time } \\
\text { Span } \\
\text { (Years) }\end{array}$} & \multicolumn{2}{|c|}{$\begin{array}{l}\text { Compound rate } \\
\text { per change }\end{array}$} & \multirow[t]{2}{*}{ Period } \\
\hline & & (ha) & $\%$ & & (ha/yr) & (\%/year) & \\
\hline 1986 & 1044.71 & & & & & & \\
\hline \multirow{3}{*}{2002} & \multirow{3}{*}{2033.06} & 988.35 & 94.6 & 16 & 61.77 & 4.25 & $1986-2002$ \\
\hline & & \multirow[b]{2}{*}{5900.9} & \multirow[b]{2}{*}{290.25} & & \multirow[b]{2}{*}{368.81} & \multirow[b]{2}{*}{9.5} & \multirow[b]{2}{*}{$2002-2018$} \\
\hline & & & & 16 & & & \\
\hline
\end{tabular}

Table 7. Urban expansion with Population Increase

\begin{tabular}{ccccc}
\hline Year & Population & $\begin{array}{c}\text { Pop. Density } \\
\text { per km } \mathbf{k m}^{2}\end{array}$ & $\begin{array}{c}\text { Urban } \\
\text { area (ha) }\end{array}$ & $\begin{array}{c}\text { Rate of } \\
\text { change }\end{array}$ \\
\hline 1986 & 162085.6 & 1095.187 & 1044.71 & 0.00 \\
2002 & 253162.3 & 1716.029 & 2033.06 & 988.35 \\
2018 & 419058.1 & 2743.834 & 7934.06 & 5900.9 \\
Source: Authors' survey, 2018 & & &
\end{tabular}

Table 7 above shows the extent of urban area as well as the population increase between 1986 and 2018. Built-up area and population projection 
analysis (Table 7) indicates that population change has great impacts on land use changes. The result shows an increase in the population of Osogbo from 162086 to 253162 between 1986 and 2012 led to a corresponding increase in urbanised land from 1044.71 ha to about 2 033.06ha. The result also shows that the population further increased to 419058 in 2018. This has led to an increased urbanised area of $7934.06 \mathrm{ha}$ in 2018. The rapid increase in population and urbanised areas has a greater effect on riparian zones and dense vegetation, as well as cultivated area. This means that built-up areas are rapidly expanding at the detriment of agricultural land (e.g. riparian zones, dense vegetation and bare land/cultivated area) (see Table 3).

The major reason for urban expansion of the study area is the relocation of the state capital between 1986 and 2002. The location of the state capital is also linked with the construction of the state secretariat in Abere. These shifted physical development towards Owode and Akoda. Another reason could be associated with the establishment of the Osun State University, Osogbo in the Okebaale area between 2002 and 2018. This brought about the need to build more hostels and residential houses. Furthermore, road development and social amenities across the town and the outskirts brought about a rapid population increase as most of the residents took advantage of the cheaper cost of land in order to enjoy the facilities. As a result, the population of the study area began to grow rapidly. Additionally, forested lands of nearby villages were turning to open surface while the city centre is becoming more over crowded. Uncontrolled migration and unbalanced distribution of the population were also some of the causes of the population increase. The city was not only the place where this was felt but also the nearby area which is also becoming more urbanised. All of the above have caused land use and land cover change resulting in a loss of agricultural land in the study area.

\section{Policy Implications}

Agricultural land within the urban centre is a vital resource that can be used for the survival of the urban poor in Nigeria and other developing countries in Africa. It can be used to improve the economic situation of the poor even in the face of urbanisation. It is a vital element for household survival strategies in urban centres of developing countries through the improvement of the economic base of the household. However, due to poor urban planning, coupled with an uncontrolled increase in population, a significant loss of agricultural land has been experienced. The problem of agricultural loss can be dealt with if there is an enabling environment that can promote sustainable agriculture land use. Programmes and legislation can be introduced to ensure that urban agriculture is sustained within the city. There is no single solution to urban agricultural planning. For planning to evolve, dialogue between different stakeholders from city officials to women farmers, among others, should be made. 


\section{Conclusion and Recommendations}

This study examined the impact of urban expansion on agriculture land in Osogbo with the use of multi-temporal imageries between 1986 and 2018. The results revealed that urban expansion has declined agricultural land from 127 70.01ha (86.28\%) to $6146.62 \mathrm{ha}(41.53 \%)$ between 1986 and 2018, indicating a decrease of -6623.39 ha. The study also shows that population growth has influenced the expansion of the built-up area at the expense of other land uses. This shows that there is considerable land use and land cover change in the study area. Agricultural land is being rapidly converted into built-up areas (such as commercial, residential, educational, industrial and other urban uses) without any systematic development plan (such as master plan). The attraction of people towards the urban area is high and the ratio of land use and land cover change is increasing day by day.

In order to ensure the sustainable development and food security in the study area there is a need to balance urbanisation and proper consumption of the agricultural area. The study therefore recommends that government should integrate agricultural lands into urban land use planning for efficient management and protection of the dwindling agricultural space. Government should also incorporate real-time remote sensing data and geospatial technology in monitoring urban expansion. Protection measures like stricter urban plans and policies, which are essential for the protection of agricultural areas, should be made. Finally, governments in Nigeria and other developing countries in Africa should support and promote urban agriculture by formalising land use through physical planning and development regulations.

\section{References}

Addo, K.A. (2010). Urban and Peri-Urban Agriculture in Developing Countires studies using Remote Sensing and In Situ Methods. Remote Sensing, 2, pp.497-513. doi:10.3390/rs2020497

Adeniyi, P.O. \& Omojola, A. (1999). Land use/Land cover change evaluation in Sokoto-Rima Basin of N.W. Nigeria based on Archival Remote sensing and GIS techniques. In P.O. Adeniyi (Ed.), Geo-information Technology Application for Resource and Environmental Management in Africa. AARSE, pp. 143-172.

Ajibola, M.O., Adewale, B.A. \& Ijasan, K.C. (2012). Effects of Urbanisation on Lagos Wetlands. International Journal of Business and Social Science, 3(17), pp.310-318.

Ashbindu Singh, H.S., Foresman, T. \& Eugene, A.F. (2001). Status of world's remaining closed forests: An assessment using satellite data and policy options. Journal of the Human Environment, 67-69, pp.10.

Cofie, O.O., Veenhuizen, R. \& Drechsel, P. (2003). Contribution of Urban and Peri-urban Agriculture to Food security in Sub-Saharan African. Paper presented at Africa session of $3^{\text {rd }}$ WWF, Kyoto, $17^{\text {th }}$ March, 2003. 
Dekolo, S., Oduwaye, L. \& Nwokoro, I. (2016). Urban Sprawl and Loss of Agricultural Land in Peri-urban Areas of Lagos. Munich Personal RePEc Archive. 5(2). pp.20-33.

Enaruvbe G.O \& Atedhor G.O. (2015). Spatial Analysis of Agricultural landuse change in Asaba, Southern Nigeria. Ife Journal of Science. 17(1), pp. $65-74$

Fabiyi, O.O. (2006). Urban Land Use Change Analysis of a Traditional City from Remote Sensing Data: The Case of Ibadan Metropolitan Area, Nigeria. Human and Social Sciences Journal, 1(1), pp.42-64.

Fournier, F. (1996). The city: so human an ecosystem. Natural Resources, 32, pp.1-16.

Gasu, M.B., Nicholas, E., Bidmus, M.A. \& Dawam, P. (2016). Geospatial Analysis of Land use Dynamics in Osogbo between 1986 and 2012. Abuja Journal of Geography and Development, 4(1), pp.1-18.

Kharel, G. (2010). Impacts of Urbanization on Environmental Resources: A Land Use Planning Perspective. M.Sc Thesis, Department of City and Regional Planning, University of Texas at Arlington.

Kulak, M., Graves, A. \& Chatterton, J. (2013). Reducing greenhouse gas emissions with urban agriculture: a life cycle assessment perspective. Landscape and urban planning, 11(1), pp.68-78.

Kumar, V.\& Kumar, V. (2016). Urban Spatial Growth and Landuse Change Detection Analysis of Aligarh City, Uttar Pradesh, India Using High Resolution Remote Sensing Data, Geographical Information System (Gis) And Global Positioning System (Gps) Techniques International Journal of Engineering Technologies and Management Research, 3(9), pp1-11.

Marcotullio, P.J., Braimoh, A.K. \& Onishi, T. (2008). The impact of urbanization on soils. In Braimoh, A.K. \& Vlek, P.L.G. (Eds.), Land use and soil resources. Sweden: Springer, pp.201-250.

Mir, A.A., Ahmed, P., Bhat, P.A. \& Singh, H. (2016). Analyzing Land Use/Land Cover Change Using Remote Sensing and GIS Techniques in Pohru Watershed of Kashmir Valley. Journal of Research and Development, 16, pp.104-111.

Mougeot, Luc J.A. (2005). ACROPOLIS. The Social, Political and Environmental Dimensions of Urban Agriculture. London: Earthscan.

Naab F.Z., Dinye R.D. \& Kasanga R.K. (2013). Urbanisation and Its Impact on Agricultural lands in growing cities in Developing Countries: A case study of Tamale in Ghana. Modern Social Science Journal, 2(2), pp.256-287.

Nugent, R. (2000). The impact of urban agriculture on the household and local economies. In: Bakker, N.M., Dubbeling, S., Guendel, U., Sabel Koschella, H. \& de Zeeuw (eds.). Growing Cities, Growing Food, urban agriculture on the policy agenda. DSE Germany, pp.67-97.

Oloukoi J., Oyinloye R.O. \&Yadjemi, H. (2014). Geospatial analysis of urban sprawl in ile-ife city, Nigeria. South African Journal of Geomatics, 3(2), pp.128-144.

Rees, W.E. (1997). Why Urban Agriculture? Notes for the IDRC Development Forum on Cities Feeding People: A Growth Industry. Vancouver: Canada's Office of Urban Agriculture. Available at: http://www.cityfarmer.org/rees.html 
Schmidt, E. \& Kedir, M. (2009). Urbanization and Spatial Connectivity in Ethiopia: Urban Growth Analysis Using GIS. International Food Policy Research Institute (IFPRI). Ethiopia Strategy Support Programe 2 (ESSP2), Discussion Paper No. ESSP2 003.

Tokula, A.E. \& Ejaro, S.P. (2013). Dynamics of land use/land cover changes and its implication on food security in Anyigba, North Central Nigeria. Conference Journal of Environmental Studies, 7, pp.42-52.

UN-HABITAT, (2008). State of the African Cities Report 2008: A Framework for Addressing Urban Challenges in Africa. Nairobi: United Nations Human Settlements Programme

Wu, Q., Li, H., Wang, R., Paulussen, J., Hec, Y., Wang, M. \& Wang, Z. (2006). Monitoring and predicting land use change in Beijing using remote sensing and GIS. Landscape and Urban Planning, 78(4), pp.322-333.

Yuan, F., Sawaya, K.E., Loeffelholz, B.C. \& Bauer, M.E. (2005). Land cover classification and change analysis of the twin cities (Minnesota) metropolitan area by multi-temporal land sat remote sensing. Remote Sensing of Environment, 98(2-3), pp.317-328. 